\title{
Hubungan Teknik, Frekuensi, Durasi Menyusui dan Asupan Energi dengan Berat Badan Bayi Usia 1-6 Bulan di Puskesmas Tasikmadu Kabupaten Karanganyar
}

\section{Relations Techniques, Frequency, Duration of Breastfeeding and Energy Intake With Weight Babies in Age 1-6 Months At Tasikmadu Sub-District Karanganyar District}

\author{
Dewi Kartika Sari*1, Didik Gunawan Tamtomo ${ }^{1}$, Sapja Anantayu ${ }^{1}$
}

\begin{abstract}
ABSTRAK
Latar Belakang: Berat badan merupakan indicator pertama dalam menilai pertumbuhan bayi. Upaya untuk meningkatkan berat badan bayi diperlukan gizi yang maksimal dan ASI merupakan makanan utama bagi bayi terutama pada usia 1-6 bulan.

Tujuan: Penelitian ini bertujuan untuk mengnalisis faktor yang berkaitan dengan pemberian ASI dan dilihat pencapaian berat badan. Faktor yang dimaksud meliputi teknik, frekuensi, durasi menyusui dan asupan enegi dengan berat badan bayi usia 1-6 bulan.

Metode: Desain dalam penelitian ini adalah kohort prostektif karena mengikuti berat badan bayi selama 4 bulan. Sampel dalam penelitian ini adalah ibu yang memiliki bayi usia 1-6 bulan yang diambil secara purposive sampling pada titik awal penelitian berjumlah 60 responden dan dropout sebayak 14 responden sehingga yang dapat dianalisis sebesar 46 responden. Analisis data secara bivariat dilakukan dengan chi square dan multivariate dengan uji regresi logistic ganda.

Hasil: Dari hasil penelitian menunjukan hasil adanya hubungan antara teknik menyusui dan berat badan bayi dengan $p$-value $=0,003$, ada hubungan antara frekuensi menyusui dengan berat badan bayi dengan $p$-value $=0,018$ ada hubungan durasi menyusui dengan berat badan bayi dengan $p$ value $=0,001$ dan ada hubungan antara asupan energi dengan berat badan bayi dengan $p$ value $<0,001$. Dari analisis multivariate dari keempat variabel bebas, asupan energi merupakan yang paling berpengaruh diantara variabel lainya dengan exp (B) sebesar 38,822 yang berarti jika asupan energi ibu menyusui baik maka beresiko 38,822 kali mengalami kenaikan berat badan.

Kesimpulan: Terdapat hubungan antara teknik, frekuensi, durasi menyusui dan asupan energi ibu dengan berat badan bayi usia 1-6 bulan.
\end{abstract}

Kata kunci: teknik menyusui, durasi menyusui, frekuensi menyusui, asupan energi ibu menyusui, berat badan bayi 


\begin{abstract}
Background: Weight is the first indicator for baby's growth value. Eforts to increasing the baby's weight is maximise the nutrients and mother's milk as the primmary food for baby on 1-6 months. Objective: This research was conducedt to analyze relation factors with giving mother's milk and the view of weight accomplishment. This factors such as technique, frequency, sucking duration and the intake of energy with baby's weight on 1-6 months.

Methods: Design in this reserach is cohort prostective to follwoing the baby's weight as long as 4 months. Sample in this research are baby's mother on 1-6 months which was taken by purpossive sampling in the beginning of this research are 60 respondent and fall 14 respondent, 46 respondent were been analyze. Data analyze was obtained with chi square and multivariate with multiple logistic of regression test.

Results: This research showed that has relation betweeen breasfeeding technique with baby's weight by $p$-value $=0.003$, there is relation between breasfeeding frequency with baby's weight by $p$ value $=0.018$, there is relation between breasfeeding duration with baby's weight by $p$-value $=0,001$, there is relation between the intake of energy with baby's weight by $p$-value $<0.001$. The intake of energy has impact of the multivariate analyze from independent variable by exp (B) 38.822 it has means risk to 38.822 times will increasing weight if mothers's intake energy is good.

Conclusion: There are relation between technique, frequency, sucked duration and the intake of the energy with baby's weight on 1-6 months.
\end{abstract}

Keywords: breastfeeding technique, breastfeeding duration, breastfeeding frequency, mother's intake of energy, baby's weight

\footnotetext{
*Koresponden:

kartikasastradewi@yahoo.co.id

${ }^{1}$ Pascasarjana Ilmu Gizi Universitas Sebelas Maret
} 


\section{PENDAHULUAN}

Gerakan 1000 Hari Pertama Kehidupan adalah upaya perbaikan gizi sejak dimulainya kehamilan sampai pasca persalinan atau sampai bayi berusia 2 tahun. Program tentang upaya perbaikan gizi ini tentunya tidak hanya berfokus pada kehamilan saja, namun sampai bayi berusia 2 tahun setelah lahir yang pada 1000 hari pertama kehidupan tersebut janin dan bayi membutuhkan gizi yang optimal untuk mendukung pertumbuhan dan perkembanganya ${ }^{1}$.

Pada dasarnya pertumbuhan dibagi menjadi dua, yaitu pertumbuhan linier dan pertumbuhan masa jaringan. Pertumbuhan linier dikaitkan dengan status gizi pada masa lampau dan pertumbuhan masa jaringan adalah menggambarkan status gizi sekarang atau pada saat pengukuran. Ukuran yang paling sering digunakan adalah berat badan ${ }^{2}$. Berat badan merupakan ukuran antopometrik yang terpenting dan harus diukur pada setiap kesempatan memeriksa kesehatan anak pada semua kelompok umur. Berat badan merupakan hasil penurunan atau peningkatan semua jaringan yang ada di dalam tubuh, antara lain tulang, otot, lemak, cairan tubuh dan lain lain ${ }^{3}$.

Air susu Ibu (ASI) merupakan makanan yang utama dan paling sempurna bagi bayi terutama bayi berusia kurang dari 6 bulan. ASI mengandung semua zat gizi yang dibutuhkan bayi untuk proses pertumbuhan dan perkembanganya ${ }^{4}$. ASI yang diberikan kepada bayi harus optimal untuk proses pertumbuhanya ${ }^{5}$. Pemantauan pertumbuhan bayi dapat dipantau dengan menimbang berat badan anak setiap bulan dan hasil penimbangan diterjemahkan dalam buku KMS untuk menghasilkan status pertumbuhan balita (Naik atau Tidak Naik) ${ }^{6}$. Saat ini pemerintah lebih mengutamakan balita yang tidak naik berat badanya atau $\mathrm{T}, \mathrm{T}$ adalah balita yang tidak naik berat badanya, tetap atau naik tetapi tidak mengikuti garis pertumbuhan?.

Berdasarkan Profil Kesehatan Indonesia pada tahun 2014 dari 2.000.200 jumlah bayi usia 0-6 bulan yang mendapat ASI Eksklusif hanya 1.046.173 (52,3\%). Untuk propinsi Jawa
Tengah dari jumlah 260.419 bayi usia 0-6 bulan yang mendapat ASI Eksklusif sebesar 156.124 bayi sedangkan dari data bulan Oktober 2015 di Kabupaten Karanganyar dari 5.138 bayi usia 1-6 bulan yang ditimbang, 3.010 diantaranya mendapat ASI Eksklusif dan yang mengalami T (Tidak naik) sebesar 259 bayi, hal ini menunjukan bayi yang mendapat ASI Eksklusif dan mengalami T sebanyak 8,6\%. Di Puskesmas Tasikmadu, dari dari 251 bayi usia 1 - 6 bulan yang datang dan ditimbang, 165 diantaranya mendapat ASI Eksklusif dan yang mengalami $T$ sebesar 38 bayi, hal ini menunjukan bayi yang mendapat ASI eksklusif dan mengalami $T$ sebesar $0,23 \%$. Agar pertumbuhan bayi baik terutama dilihat dari berat badan tentunya pemberian ASI harus lebih optimal dan proses pemberian ASI dilakukan melalui kegiatan laktasi. Proses laktasi merupakan proses produksi dan sekresi $\mathrm{ASI}^{8}$. Agar proses laktasi berjalan lancar maka perlu dukungan dari ibu menyusui tersebut selama proses laktasi terutama kondisi kesehatan ibu menyusui baik secara fisik dan psikis karena jika kondisi kesehatan ibu baik maka akan berpengaruh pada produksi dan pengeluaran ASI selama proses laktasi ${ }^{9}$.

Banyak faktor yang mempengaruhi proses laktasi terutama teknik menyusui, frekuensi, durasi dan gizi ibu menyusui tersebut ${ }^{10}$, jika teknik menyusui baik maka proses laktasi berjalan lancar namun banyak ibu menyusui tidak menyusui bayinya dikarenakan salah managemen laktasi terutama dengan teknik menyusuinya ${ }^{11}$. Kesalahan tatalaksana laktasi ini mengakibatkan timbulnya rasa sakit pada puting sehingga ibu berhenti melakukan proses laktasi, selain itu kesalahan tatalaksana juga mengakibatkan jumlah ASI yang dikonsumsi bayi tidak optimal ${ }^{10}$.

Frekuensi menyusui juga merupakan hal yang berpengaruh pada peningkatan berat badan bayi, semakin tinggi frekuensi menyusu maka bayi mendapat gizi yang lebih optimal sehingga berat badannya meningkat. Memberikan ASI secara on-demand atau menyusui kapanpun bayi meminta adalah cara terbaik karena dapat mencegah masalah pada proses menyusui dan bayi tetap kenyang ${ }^{12}$. Selain frekuensi, durasi menyusui juga 
berpengaruh, dimana jika durasi menyusu lama maka bayi akan mendapat sehingga bayi menerima asupan foremilk dan hindmilk secara seimbang ${ }^{13}$.

Ibu menyusui memerlukan gizi yang lebih banyak terutama kebutuhan energi yang lebih banyak dari pada saat hamil karena memerlukan tambahan 800 kkal yaitu 600 kkal untuk produksi ASI dan 200 kkal digunakan untuk aktivitas selama menyusui ${ }^{10}$. Gizi tambahan yang diperlukan tidak hanya diugunakan untuk kebutuhan tubuh ibu menyusui saja, tetapi juga untuk produksi ASI yang diberikan kepada bayinya ${ }^{9}$. Protein juga dibutuhkan dalam makanan tambahan untuk mempertahankan produksi ASI, maka dari itu diperlukan asupan energi yang baik sesuai dengan AKG. Jika gizi yang didapat ibu menyusui tercukupi dengan baik, maka ASI yang diproduksi akan lancar dan memiliki kandungan gizi yang baik pula ${ }^{5}$. Untuk mengatasi masalah tersebut tentunya perlu dilakuan penelitian lebih mendalam tentang penyebab tidak naiknya berat badan pada bayi usia 1-6 bulan. Diperlukan penelitian tentang "hubungan teknik, frekuensi, durasi menyusui dan asupan energi ibu menyusui terhadap kenaikan berat badan bayi usia 1-6 bulan di Puskesmas Tasikmadu Kabupaten Karanganyar Provinsi Jawa Tengah".

Tujuan penelitian ini untuk menganalisis hubungan teknik, frekuensi, durasi menyusui dan asupan energi ibu terhadap berat badan bayi usia 1-6 bulan di Puskesmas Tasikmadu Kabupaten Karanganyar Provinsi Jawa Tengah.

\section{METODE}

Penelitian ini menggunakan obeservasional analitik dengan desain kohort prospektif. Lokasi penelitin dilakukan di Kecamatan Tasikmadu Kabupaten Karanganyar Jawa Tengah dengan waktu penelitian bulan Februari 2016 sampai Mei 2016.
Populasi dalam penelitian ini ibu menyusui yang mempunyai bayi 1-6 bulan. Sampel diambil dengan purposive sampling dengan mengikuti berat badan bayi selama 4 bulan. Untuk titik awal penelitian dimulai saat bayi usia 1 dan 2 bulan dan didapatkan 60 sampel kemudian diikuti sampai usia 5 dan 6 bulan. Selama penelitian 4 bulan didapatkan jumlah sampel dropout sebesar 14 sampel sehingga yang dapat dianalisis sebesar 46 sampel. Analisis data bivariat menggunakan Chi Square dan multivariate menggunakan uji regresi logistic ganda.

\section{HASIL DAN PEMBAHASAN}

Jumlah Sampel Droupout

Penelitian berlangsung dalam waktu 4 bulan mulai dari bulan Febuari - Mei 2016, untuk tabel jumlah sampel dapat dilihat pada Tabel 2.

Pada awal penelitian jumlah sampel sebesar 60 ibu menyusui beserta bayinya, namun ada 3 orang dropout pada bulan kedua dikarenakan penambahan susu formula, pada bulan ketiga di dropout 7 bayi dikarenakan 4 orang karena penambahan susu formula dan 3 bayi mengalami sakit, sedangkan untuk bulan ke 4 dropout 4 bayi dikarenakan 2 bayi sakit dan 2 bayi penambahan susu formula. Total dropout sebesar 14 sampel, dropout dikarenakan penambahan susu formula sebesar 9 sampel $(64,2 \%)$ dan sebesar 5 sampel $(35,8 \%)$ dikarenakan sakit. Total sampel droput sebagian besar dikarenakan penambahan susu formula hampir semua dialami oleh bayi yang mempunyai ibu bekerja karena cuti yang diberikan oleh perusahaan selama 2 bulan, sehingga jika masa cuti habis maka ibu mengganti ASI dengan susu formula untuk mencukupi gizi bayinya,jadi hasil ahir yang bisa dianalisis sebesar 46 sampel. 
Tabel 1. Jumlah Sampel Dropout Pada Penelitian

\begin{tabular}{llll}
\hline Bulan & Jumlah Sampel & Dropout & Keterangan \\
\hline Bulan Ke-1 & 60 & - & - \\
Bulan Ke-2 & 57 & 3 & 3 bayi diberikan susu formula \\
Bulan Ke-3 & 50 & 7 & $\begin{array}{l}\text { 4 bayi diberikan susu formula \& } \\
\text { 2 bayi mengalami sakit } \\
\text { 2 bayi mengalami sakit }\end{array}$ \\
Bulan Ke-4 & 46 & 4 & \\
\hline Total Dropout & & 14 & \\
\hline
\end{tabular}

Tabel 2. Distribusi Frekuensi Berdasarkan Karakteristik Subjek.

\begin{tabular}{llcc}
\hline Variabel & Kategori & Jumlah (n=orang) & $\begin{array}{c}\text { Presentase } \\
\text { (\%) }\end{array}$ \\
\hline Jenis Kelamin & Laki-laki & 19 & 41,3 \\
Usia Ibu & Perempuan & 27 & 58,7 \\
& $<$ 20 Tahun & 0 & 0 \\
Paritas & 20-35 Tahun & 41 & 89,1 \\
& $>35$ Tahun & 5 & 10,9 \\
\multirow{3}{*}{ Pendidikan } & 1 Kali & 12 & 26,1 \\
& 2-4 Kali & 33 & 71,7 \\
& $>5$ Kali & 1 & 2,2 \\
& Tamat SD & 3 & 6,5 \\
Penghasilan & Tamat SMP & 16 & 34,8 \\
& Tamat SMA & 25 & 54,3 \\
& Tamat PT & 2 & 4,3 \\
Pekerjaan & LUMR & 11 & 23,9 \\
& UMR & 11 & 23,9 \\
& $>$ UMR & 24 & 52,2 \\
& IRT & 37 & 80,4 \\
& Karyawan Swasta & 7 & 15,2 \\
\hline
\end{tabular}

Hasil Analisis Univariat, Bivariat dan Multivariat.

Analisis Univariat Karakteristik Subjek Penelitian

Karakteristik subjek penelitian meliputi jenis kelamin, umur ibu, paritas, pendidikan ibu, penghasilan keluarga dan pekerjaan ibu telah dilaksanakan uji statistik untuk melihat distribusi frekuensi pada setiap kelompok. Dari Tabel 3 dapat dilihat karakteristik subjek diperoleh sebagai berikut.

Berdasarkan Tabel 2 didapatkan hasil sebagai berikut: Jenis kelamin, terdapat 19 bayi $(41,3 \%)$ berjenis kelamin laku-laki dan 27 bayi $(58,7 \%)$ berjenis kelamin perempuan, hal ini menunjukan bahwa sebagian besar bayi berjenis kelamin perempuan. Usia ibu, terdapat 41 orang $(89,1 \%)$ berusia $20-35$ tahun, hal ini menunjukan bahwa hampir seluruhnya ibu berusia 20-35 tahun. Paritas ibu, terdapat 33 ibu $(71,7 \%)$ multipara atau sedang menyusui anak ke 2-4, hal ini menunjukan sebagian besar ibu multipara. Pendidikan ibu, terdapat 25 ibu (54,3\%) tamat SMA, hal ini menunjukan sebagian besar ibu berpendidikan tamat SMA. Penghasilan keluarga, terdapat 24 keluarga (52,2\%) berpenghasilan >UMR, hal ini menunjukan bahwa sebagian besar keluarga berpenghasilan > UMR. Pekerjaan ibu, terdapat $37 \mathrm{ibu}(80,4)$ bekerja sebagai ibu rumah tangga, hal ini menunjukan bahwa hampir seluruhnya ibu bekerja sebagai ibu rumah tangga. 
Tabel 3. Distribusi Frekuensi Variabel Penelitian

\begin{tabular}{llcc}
\hline Variabel & Kategori & Frekuensi & Presentase (\%) \\
\hline Teknik Menyusui & Kurang Baik & 34 & 73,9 \\
\multirow{2}{*}{ Frekuensi } & Baik & 12 & 26,1 \\
& Kurang Baik & 15 & 32,6 \\
Durasi & Baik & 31 & 67,4 \\
& Kurang Baik & 32 & 69,6 \\
Asupan Energi & Baik & 14 & 30,4 \\
& <AKG & 33 & 71,7 \\
Berat Badan & $>$ AKG & 13 & 28,3 \\
& Tidak Naik & 32 & 69,6 \\
& Naik & 14 & 30,4 \\
\hline
\end{tabular}

Tabel 4. Asupan Energi, Karbohidrat, Protein dan Lemak.

\begin{tabular}{llll}
\hline Asupan & Mean \pm SD & Min & Max \\
\hline Energi(Kkal) & $2189,07 \pm 374,378$ & 1641 & 3184 \\
Karbohidrat (gram) & $247,05 \pm 61,021 \mathrm{a}$ & 153 & 481 \\
Protein (gram) & $75,27 \pm 14,384$ & 51 & 114 \\
Lemak (gram) & $107,14 \pm 17,556$ & 80 & 148 \\
\hline
\end{tabular}

Distribusi Frekuensi Variabel Penelitian

Distribusi variabel penelitian meliputi teknik menyusui, frekuensi menyusui, durasi menyusui, asupan energi dan berat badan dapat dilihat pada Tabel 3.Berdasarkan Tabel 3 tentang distribusi frekuensi variabel penelitian diketahui: Teknik menyusui, terdapat 34 sampel $(73,9 \%)$ teknik meyusuinya kurang baik, hal ini menunjukan lebih dari setengahnya mempunyai teknik menyusui yang kurang baik. Frekuensi menyusui, terdapat 31 sampel $(67,4 \%)$ frekuensi menyusuinya baik, hal ini menunjukan sebagian besar frekuensi menyusuinya baik. Durasi menyusui, terdapat 32 sampel $(69,6 \%)$ durasi menyusuinya kurang baik hal ini menunjukan bahwa sebagian besar durasi menyusuinya kurang baik. Asupan energi ibu menyusui, terdapat 33 sampel $(71,7 \%)$ asupan energinya kurang dari AKG, hal ini menunjukan bahwa sebagian besar asupan energi pada ibu menyusui kurang dari AKG.

Berat badan, bayi terdapat 32 sampel $(69,6 \%)$ berat badanya tidak naik, hal ini menunjukan bahwa sebagian besar bayi usia 1-6 bulan mengalami T (Tidak Naik) berat badanya.

Diskripsi Asupan Energi, Karbohidrat, Protein dan Lemak

Asupan Energi meliputi Energi, Karbohidrat, Protein dan Lemak dijelaskan pada Tabel 4 berikut ini:

Berdasarkan Tabel 4 diketahui rata rata asupan energi pada ibu menyusui di Kecamatan Tasikmadu sebesar 2189,07 kKal, rata-rata asupan karbohidrat 247,05 gram, rata-rata asupan protein 75,27 gram dan ratarata asupan lemak 107,14 gram, hal ini berarti lemak sebagai penyumbang energi paling tinggi dari pada protein dan karbohidrat.

Analisis Bivariat

Hubungan Teknik Menyusui dengan Berat Badan Usia 1-6 Bulan di Kecamatan Tasikmadu Kabupaten Karaganyar dapat dilihat dari Tabel 5. 
Tabel 5.Hubungan Teknik Menyusui dengan Berat Badan Usia 1-6 Bulan di Kecamatan Tasikmadu Kabupaten Karaganyar

\begin{tabular}{|c|c|c|c|c|c|c|c|c|}
\hline \multirow{3}{*}{ Teknik Menyusui } & \multicolumn{6}{|c|}{ Berat Badan } & \multirow{3}{*}{ p-value } & \multirow{3}{*}{ RR } \\
\hline & \multicolumn{2}{|c|}{ Tidak Naik } & \multicolumn{2}{|r|}{ Naik } & \multicolumn{2}{|c|}{ Total } & & \\
\hline & $\mathbf{F}$ & $\%$ & $\mathbf{F}$ & $\%$ & $F$ & $\%$ & & \\
\hline Kurang Baik & 28 & 82,4 & 6 & 17,6 & 34 & 100 & 0,003 & 2.471 \\
\hline Baik & 4 & 33,3 & 8 & 66,7 & 12 & 100 & & \\
\hline Total & 32 & 69,6 & 14 & 30,4 & 46 & 100 & & \\
\hline
\end{tabular}

Tabel 6. Hubungan Frekuensi Menyusui dengan Berat Badan Usia 1-6 Bulan di Kecamatan Tasikmadu Kabupaten Karanganyar

\begin{tabular}{|c|c|c|c|c|c|c|c|c|}
\hline \multirow{3}{*}{ Frekuensi } & \multicolumn{6}{|c|}{ Berat Badan } & \multirow{3}{*}{ p-value } & \multirow{3}{*}{ RF } \\
\hline & \multicolumn{2}{|c|}{ Tidak Naik } & \multicolumn{2}{|c|}{ Naik } & \multicolumn{2}{|c|}{ Total } & & \\
\hline & $\mathbf{F}$ & $\%$ & $\mathbf{F}$ & $\%$ & $\mathbf{F}$ & $\%$ & & \\
\hline Kurang & 14 & 93,3 & 1 & 6,7 & 15 & 100 & 0,018 & 1,607 \\
\hline Baik & 18 & 58,1 & 13 & 41,9 & 31 & 100 & & \\
\hline Total & 32 & 69,6 & 14 & 30,4 & 46 & 100 & & \\
\hline
\end{tabular}

Berdasarkan Tabel 5 merupakan hasil uji Chi Square diketahui signifikan atau $p$ value $=0,003$ atau lebih kecil dari $\alpha=0,05$ sehingga $\mathrm{HO}$ ditolak, hal ini menunjukan ada hubungan yang bermakna antara teknik menyusui dengan berat badan bayi usia 1-6 bulan. Berdasarkan nilai RR didapatkan hasil 2.471 hal ini dapat disimpulkan bahwa ibu dan bayi yang mempunyai teknik menyusui yang baik kemungkinan mengalami 2.471 kali peningkatan berat badan bayi usia 1-6 bulan.

Hubungan Frekuensi Menyusui dengan

Berat Badan Usia 1-6 Bulan di Kecamatan Tasikmadu Kabupaten Karaganyar dapat dilihat dari Tabel 6. Berdasarkan Tabel 6 merupakan hasil uji Chi Square diketahui signifikan atau $p$-value $=0,018$ atau lebih besar dari $\alpha=0,05$ sehingga $H_{0}$ ditolak, hal ini menunjukan ada hubungan yang bermakna antara frekuensi menyusui dengan berat badan bayi usia 1-6 bulan. Berdasarkan nilai RR didapatkan hasil 1,607 hal ini dapat disimpulkan bahwa bayi yang mempunyai frekuensi menyusui yang baik kemungkinan mengalami 1,607 kali peningkatan berat badan bayi usia 1-6 bulan.

Hubungan durasi menyusui dengan berat badan usia 1-6 bulan di Kecamatan Tasikmadu Kabupaten Karaganyar dapat dilihat dari Tabel 7.

Tabel 7. Hubungan Durasi Menyusui dengan Berat Badan Usia 1-6 Bulan di Kecamatan Tasikmadu Kabupaten Karaganyar

\begin{tabular}{|c|c|c|c|c|c|c|c|c|}
\hline \multirow{3}{*}{ Durasi } & \multicolumn{6}{|c|}{ Berat Badan } & \multirow{3}{*}{$p$-value } & \multirow{3}{*}{$\mathbf{R R}$} \\
\hline & \multicolumn{2}{|c|}{ Tidak Naik } & \multicolumn{2}{|r|}{ Naik } & \multicolumn{2}{|c|}{ Total } & & \\
\hline & $F$ & $\%$ & $\mathbf{F}$ & $\%$ & $\mathbf{F}$ & $\%$ & & \\
\hline Kurang & 27 & 84,4 & 5 & 15,6 & 32 & 100 & 0,001 & 2.362 \\
\hline Baik & 5 & 35,7 & 9 & 64,3 & 14 & 100 & & \\
\hline Total & 32 & 69,6 & 14 & 30,4 & 46 & 100 & & \\
\hline
\end{tabular}


Tabel 8. Hubungan Asupan Energi dengan Berat Badan Usia 1-6 Bulan di Kecamatan Tasikmadu Kabupaten Karanganyar

\begin{tabular}{|c|c|c|c|c|c|c|c|c|}
\hline \multirow{3}{*}{$\begin{array}{c}\text { Asupan } \\
\text { Energi }\end{array}$} & \multicolumn{6}{|c|}{ Berat Badan } & \multirow{3}{*}{ p-value } & \multirow{3}{*}{$\mathbf{R R}$} \\
\hline & \multicolumn{2}{|c|}{ Tidak Naik } & \multicolumn{2}{|r|}{ Naik } & \multicolumn{2}{|c|}{ Total } & & \\
\hline & $\mathbf{F}$ & $\%$ & $\mathbf{F}$ & $\%$ & $\mathbf{F}$ & $\%$ & & \\
\hline$<A K G$ & 29 & 87,9 & 4 & 12,1 & 33 & 100 & 0,000 & 3,808 \\
\hline$>A K G$ & 3 & 23,1 & 10 & 79,9 & 13 & 100 & & \\
\hline Total & 32 & 69,6 & 14 & 30,4 & 46 & 100 & & \\
\hline
\end{tabular}

Berdasarkan Tabel 7 merupakan hasil uji Chi Square diketahui signifikan atau $p$-value $=0,001$ atau lebih kecil dari $\alpha=0,05$ sehingga $\mathrm{H}_{0}$ ditolak, hal ini menunjukan ada hubungan yang bermakna antara durasi menyusui dengan berat badan bayi usia 1-6 bulan. Berdasarkan nilai RR didapatkan hasil 2.362 hal ini dapat disimpulkan bahwa bayi yang mempunyai durasi menyusui yang baik kemungkinan mengalami 2.362 kali peningkatan berat badan bayi usia 1-6 bulan .

Hubungan Asupan Energi dengan Berat Badan Usia 1-6 Bulan di Kecamatan Tasikmadu Kabupaten Karaganyar dapat dilihat dari Tabel 8.

Berdasarkan Tabel 8 merupakan hasil uji Chi Square diketahui signifikan atau $p$-value $=0,000$ atau lebih kecil dari $\alpha=0,05$ sehingga $\mathrm{H}_{0}$ ditolak, hal ini menunjukan ada hubungan yang bermakna antara asupan energi ibu menyusui dengan berat badan bayi usia 1-6 bulan. Berdasarkan nilai RR didapatkan hasil 3,808 hal ini dapat disimpulkan bahwa bayi yang mempunyai asupan energi ibu menyusui yang baik kemungkinan mengalami 3,808 kali peningkatan berat badan bayi usia 1-6 bulan .
Analisis Multivariat

Seleksi bivariat merupakan simpulan $p$ value dari hasil uji hubungan masing masing variabel dependen dengan independen dengan uji Chi Square dimana semua variabel mempunyai $p$-value $<0,25$ sehingga semua variabel bisa masuk ke dalam uji multivariat dengan menggunakan uji regresi logistic ganda.

Hubungan teknik, frekuensi, durasi menyusui, asupan energi ibu dan berat badan bayi usia 1-6 bulan di Kecamatan Tasikmadu Kabupaten Karaganyar dapat dilihat dari Tabel 9. Tabel 9 merupakan hasil uji multivariat dengan menggunakan uji regresi logistic ganda. Dari tabel diatas bisa disimpulkan bahwa asupan energi mempunyai pengaruh paling besar terhadap berat badan, hal ini dibuktikan dengan nilai $p$-value sebesar 0,003 dan $\operatorname{Exp}(B)$ sebesar 38,382 hal ini menjelaskan bahwa asupan energi yang baik maka 38,382 kali mengalami peningkatan berat badan dan hasil tersebut dapat menjelaskan berat badan sebesar $68,9 \%$ dan sisanya $31,1 \%$ dijelaskan oleh faktor lain.

Tabel 9. Hubungan Antara Teknik, Frekuensi, Durasi Menyusui dan Asupan Energi Ibu dengan Berat Badan Bayi Usia 1-6 Bulan di Kecamatan Tasikmadu Kabupaten Karaganyar

\begin{tabular}{lccrcc}
\hline \multirow{2}{*}{ Variabel } & p-value & Exp(B) & \multicolumn{2}{c}{$\mathbf{9 5 \%}$ C.I for EXP (B) } & Nagelkerke R \\
\cline { 4 - 5 } & & 11,877 & Lower & Upper & 0,689 \\
\hline Teknik & 0,051 & & 0,986 & 143,023 & \\
Menyusui & & 2,690 & & & \\
Frekuensi & 0,485 & 3,677 & 0,167 & 43,364 & \\
Durasi & 0,244 & 38,382 & 0,412 & 32,846 & \\
Asupan & 0,003 & 3,424 & 430,274 & \\
Energi & & & & & \\
\hline
\end{tabular}


Hubungan Teknik Menyusui dengan Berat Badan Bayi Usia 1-6 Bulan

Berdasarkan hasil dari Tabel 5, dapat disimpulkan bahwa ada hubungan antara teknik menyusui dan berat badan bayi 1-6 bulan, hal tersebut terbukti dengan hasil uji bivariat yang dilakukan, diperoleh hasil $p$ value sebesar 0,003 , hal ini sejalan dengan penelitian ${ }^{8}$ dimana praktek dalam menyusui berpengaruh terhadap status gizi dan salah satu indicator penilaian status gizi adalah dengan melihat berat badanya, Teknik meyusui memang penting dalam proses menyusui. Jika teknik menyusui yang dilakukan baik maka akan mengurangi ketidaknyamanan dalam menyusui sehingga ibu menyusui dapat terus memberikan ASI kepada bayinya. Menurut WHO pada tahun 2011 faktor inhibitor dalam produksi ASI adalah ketidaknyamanan dalam proses menyusui dan dalam menyusui salah satu ketidaknyamanan tersebut adalah jika teknik menyusui yang salah, jadi jika ibu nyaman dalam menyusui maka ASI yang diproduksi akan banyak. Seperti penelitian yang dilakukan di Thailand pada tahun 2012 memberikan bukti signifikan antara posisi menyusui dengan ASI eksklusif ${ }^{14}$, jika teknik menyusuinya bagus maka ibu tidak mengalami masalah dalam menyusui sehingga pemberian ASI bisa terlaksana dengan baik dan bayi mendapat gizi yang optimal yang dapat dilihat dengan penambahan berat badanya sesuai dengan kenaikan berat badan minimal pada KMS.

Pelaksanaan teknik menyusui juga didukung oleh paritas ibu dimana sebagian besar ibu tergolong multipara. Ibu yang multipara atau mempunyai anak antara 2-4 umunya mempunyai pengalaman lebih dalam mengurus bayi dibanding ibu yang masih nulipara atau masih mempunyai anak 1 terutama dalam pelaksanaan teknik menyusui, namun dalam penelitian ini pelaksanaan teknik menyusui tidak hanya dipengaruhi paritas saja tetapi juga dipengaruhi oleh pendidikan ibu, dapat dilihat bahwa pelaksaan teknik menyusui tergolong kurang baik kejadian ini disebabkan kurangnya pengetahuan ibu tentang teknik menyusui yang baik dan benar, kurangnya pengetahuan tentang teknik menyusui dapat dilihat dari pendidikan ibu dimana sebagian besar $(54,3 \%)$ ibu berpendidikan tamat SMA. Menurut penelitian yang dilakukan oleh Juliastuti pada tahun 2011 menyatakan bahwa ada hubungan antara pengetahuan dengan pemberian ASI, hal ini didukung pula oleh penelitian yang dilakukan Nizar pada tahun 2016 yang menyatakan ada hubungan antara pendidikan ibu dengan gizi kurang. Pendidikan merupakan faktor penting untuk menilai pengetahuan ibu terutama dalam proses pemberian ASI dimana teknik menyusui berperan selama proses meyusui, jika ibu mengetahui teknik menyusui yang baik dan benar maka dalam pemberian ASI pelaksaan teknik menyusuinyajuga bagus sehingga bayi mendapat gizi yang optimal yang dapat dilihat dengan peningkatan berat badanya sesuai dengan kenaikan berat badan minimal menurut KMS sehingga jika berat badannya naik sesuai KBM maka tidak akan mengalami gizi buruk.

Hubungan Frekuensi Menyusui dengan Berat Badan Bayi Usia 1-6 Bulan

Frekuensi menyusui juga berhubungan dengan berat badan bayi usia 1-6 bulan. Hal tersebut terbukti setelah dilakukan uji statistik secara bivariat ditemukan hasil yang signifikan antara frekuensi menyusui dengan berat badan bayi usia 1-6 bulan dengan $p$-value sebesar 0,018. Hal ini sejalan dengan pernyataan varney pada tahun 2007 yang menyatakan bahwa frekuensi yang baik $>8$ kali dalam 24 jam, karena lambung bayi kosong adalan 2 jam setelah minum $\mathrm{ASI}^{12}$. Frekuensi yang lebih sering dalam pemberian ASI akan memberikan gizi yang lebih optimal terhadap bayi. Frekuensi yang lebih sering juga mencegah lambung bayi kosong sehingga setiap saat bisa mencerna gizi untuk pertumbuhanya.

Durasi menyusui tentunya di dukung oleh pekerjaan ibu yang hampir seluruhnya bekerja sebagai ibu rumah tangga, hal ini sejalan dengan penelitian yang dilakuakan di New York Amerika pada tahun 2013 yang menyatakan ada hubungan yang signifikan antara pekerjaan dengan waktu pemberian $\mathrm{ASI}^{15}$. Ibu yang bekerja sebagai ibu rumah 
tangga umunya mengabiskan waktu seharihari dirumah bersama anaknya, sehingga ibu mempunyai lebih banyak bersama bayinya dan setiap saat bisa bisa menyusui secara on demand atau menyusui sesuai keinginan bayi sehinngga bayi mendapatkan gizi yang optimal yang dapat dilihat dengan kenaikan berat badanya sesuai dengan kenaikan berat badan minimal sesuai dengan KMS.

Hubungan Durasi Menyusui dengan Berat Badan Bayi Usia 1-6 Bulan

Durasi dalam menuyusui juga juga terdapat hubungan yang signifikan dengan berat badan bayi usia 1-6 bulan. Terbukti dengan hasil uji statistik yang menyatakan bahwa $p$ value sebesar 0,001 , hal ini sejalan dengan penelitian yang dilakukan Nizar et al pada tahun 2016 yang menyatakan ada hubungan antara durasi meyusui dengan kejadian gizi kurang, pernyataan Almatsier pada tahun 2011 yang menyatakan durasi menyusui yang baik > 15 menit dan pernyataan ini juga didukung oleh WHO pada tahun 2011 yang menyatakan durasi menyusui penting untuk pertumbuhan bayi agar bayi mendapatkan gizi yang sempurna pada ASI yang terdapat dalam forcemilk (ASI awal) dan hindmilk (ASI ahir). Durasi yang lama dalam menyusui akan mendapatkan gizi yang lengkap dari ASI karena mendapat ASI yang awal sampai ASI ahir. Banyaknya bayi yang mengalami $T$ atau berat badanya tidak naik sebagian besar disebabkan oleh durasi yang singkat, karena ASI yang didapat hanya ASI awal dan tidak sampai ASI ahir sehingga bayi banyak yang tidak mendapat gizi yang optimal sehingga banyak yang berat badanya tidak naik, jika kondisi ini diteruskan maka akan berakibat buruk pada bayi dan beresiko mengalami gizi kurang dan gizi buruk.

Durasi menyusui juga didukung oleh pekerjaan ibu dimana hampir selurunya $(80,4 \%)$ bekerja sebagai ibu rumah tangga. Pemberian ASI dengan durasi yang lama dapat dilakukan jika ibu mempunyai banyak waktu bersama bayinya, hal ini sejalan dengan penelitian yang dilakuakan di New York Amerika pada tahun 2013 yang menyatakan ada hubungan yang signifikan antara pekerjaan dengan waktu pemberian $\mathrm{ASI}^{15}$.
Pekerjaan yang yang setiap saat dirumah atau ibu rumah tangga, umunya menghabiskan waktu dirumah untuk mengurus keluarga terutama anaknya, jadi ibu mempunyai waktu lebih untuk menyusui bayinya tanpa membatasi waktu.

Durasi menyusui yang kurang umunya juga dipengaruhi oleh pendidikan ibu, dapat dilihat dari sebagian besar ibu yang menyusui di Kecamatan Tasikmadu berpendidikan tamat SMA. Menurut penelitian yang dilakukan oleh Juliastuti pada tahun 2011 dan penelitian yang dilakukan Nizar pada tahun 2016 menyatakan bahwa ada hubungan antara pendidikan dengan pemberian ASI. Pendidikan mencerminkan pengetahuan terutama pengetahuan tentang durasi menyusui. Di Kecamatan Tasikmadu umunya ibu tidak mengetahui pentingnya pemberian ASI dengan durasi yang lama, maka dari itu durasi menyusui yang dilaksanakan di kecamatan tasikmadu umunya kurang sehingga sebagian besar berat badan bayi mengalami T (Tidak Naik).

Hubungan Asupan Energi Ibu Menyusui dengan Berat Badan Bayi Usia 1-6 Bulan

Penelitian ini menemukan bahwa secara signifikan asupan energi berhubungan dengan berat badan bayi usia 1-6 bulan dan menunjukan hubungan yang positif antara asupan energi terhadap berat badan bayi, ditemukan bahwa sebagian besar ibu yang asupan energinya bagus maka bayi mengalami kenaikan berat badan, hal ini sejalan dengan penelitian Yang Titi dkk pada tahun 2014 yang menyatakan bahwa ada hubungan antara asupan makanan ibu dan konsentrasi makronutrien ASI, dan konsentrasi makronutrien ASI berhubungan dengan tahapan laktasi, sehingga dapat disimpulakan bahwa asupan energi yang cukup mempengaruhi kandungan energi dalam ASI, jika asupan energinya baik maka kandungan energi dalam ASI bagus dan akan meningkatkan berat badan bayi. Pernyataan ini juga didukung oleh pertyataan Pertiwi yang menyatakan bahwa energi juga diperlukan untuk produksi ASI dimana 100 cc ASI 
memerlukan $85 \mathrm{kkal}$, dan umumnya produksi ASI sehari 850 cc itu berarti sehari ibu memerlukan tambahan energi sekitar 750 $\mathrm{kkal}^{16}$.

Dalam penelitian ini ditemukan bahwa protein dan lemak menyumbang energi paling banyak pada ibu menyusui dibanding dengan karbohidrat. Hal ini sejalan dengan pernyataan Andriani bahwa lemak dan protein merupakan gizi penting untuk ibu menyusui karena lemak juga dapat menyumbang energi dengan perhitungan tiap 1 gram lemak memberi 9 kkal energi dan protein dibutuhkan untuk sintesis hormon prolaktin dan oksitosin yang digunakan untuk produksi $\mathrm{ASI}^{16}$, jika tambahan tersebut terpenuhi maka ASI yang diproduksi juga akan cukup untuk memenuhi kebutuhan bayi terutama untuk meningkatkan berat badanya.

Pendapatan keluarga mempunyai pengaruh juga terhadap asupan energi, terbukti dari sebagian besar $(87,9 \%)$ ibu yang asupanya < AKG tenyata hampir setengahnya berpendapatan $\leq$ UMR sebesar $(47,4 \%)$, hal ini sejalan dengan penelitian Nizar pada tahun 2016 yang menyatakan bahwa adanya hubungan antara pendapatan dengan gizi kurang. Pendapatan keluarga merupakkan hal penting bagi bayi. Pendapatan yang kurang menyebabkan gizi ibu dan anak tidak adekuat, sehingga jika asupan energi ibu kurang dari AKG maka sulit untuk mendapatkan peningkatan berat badan karena sumber utama makanan bayi adalah ASI yang diproduksi oleh ibu dan jika supan energi ibu kurang maka kurang pula energi yang dibutuhkan ibu untuk produksi ASInya.

Pendidikan juga berpengaruh terhadap asupan energi ibu, walaupun tidak diuji secara langsung namun dapat dilihat dari sebagian besar energi yang kurang banyak dialami oleh ibu yang berpendidikan tamat SMA, hal ini sejalan dengan penelitian Nizar pada tahun 2016 yang menyatakan pendidikan ibu berhubungan dengan kejadian gizi kurang, ibu yang bependidikan menegah umunya tidak mengerti bahwa ibu menyusui perlu penambahan asupan energi disbanding pada saat sebelum hamil, namun pada kenyataan di lapangan ibu tidak mengerti tentang penambahan asupan yang harusnya dicukupi oleh ibu menyusui, jadi banyak ibu makan tidak memperhatikan tambahan energi yang telah dianjurkan sehingga banyak ibu yang asupan energinya kurang dan menyebabkan gizi untuk memproduksi ASI kurang dan mengakibatkan banyaknya bayi yang mengalami $T$ atau berat badanya tidak naik.

Hubungan Teknik, Frekuensi, Durasi Menyusui dan Asupan Energi Ibu dengan Berat Badan Bayi Usia 1-6 Bulan

Penelitian ini juga menunjukan bahwa dari semua variabel yaitu teknik, durasi menyusui dan asupan energi yang paling berpengaruh signifikan dengan berat badan adalah asupan energi, walaupun dilihat dari signifikansi pada variable teknik, frekuensi dan durasi menyusui tidak signifikan, bukan berarti sama sekali tidak berpengaruh tetapi memliki pengaruh yang sedikit atau tidak berpengaruh secara langsung.

Berdasarkan hasil Nagerkerke R Square dengan hasil 0,689 yang berarti semua variable dapat menjelaskan berat badan sebesar $68,8 \%$, dapat diartikan bahwa semua aspek yang berhubungan dengan menyusui baik dari ibu dan anak itu penting, dapat dijelaskan dengan hasil Nagerkerke $\mathrm{R}$ Square dengan hasil 0,689 yang berarti asupan energi ibu berpengaruh dengan berat badan bayi sebesar $68,9 \%$ dan $31,1 \%$ dipengaruhi oleh faktor lain. Hal tersebut sesuai dengan penelitian yang dilakukan di Jatinangor pada tahun 2012 yang menyatakan gizi ibu berhubungan dengan pelaksanaan $\mathrm{ASI}^{1}$. ASI juga memiliki kotribusi berbeda dalam kesehatan bayi dalam penelitian yang dilakukan Boone et al pada tahun 2016 menemukan bahwa pemberian ASI berhubungan dengan penurunan resiko penyakit diare pada bayi, sehingga jika pemberian ASI berjalan lancar maka gizi bayi tepenuhi dan terhindar dari penyakit termasuk diare sehingga pertumbuhan berjalan normal dan berat badanyapun 
meningkat karena ASI merupakan makanan utama bayi jadi penting dan perlu diperhatikan lebih ${ }^{17}$.

Peneliti menduga bahwa 31,1\% faktor lain yang mempengaruhi berat badan bayi usia 1-6 bulan adalah pendidikan ibu dan penghasilan keluarga, hal ini sejalan dengan penelitian yang dilakukan Nizar et al pada tahun 2016 yang menyatakan bahwa ada hubungan yang signifikan antara pendidikan ibu dan pendapatan keluarga dengan gizi kurang sehingga. Pendidikan ibu penting untuk peningkatan berat badan, jika ibu megetahui pentingnya berat badan maka ibu akan termotivasi untuk lebih meningkatkat berat badan bayi dan pendapatan keluarga penting untuk mencukupi gizi keluarga terutama bagi ibu menyusui agar dapat memproduksi ASI dengan baik sehingga bayi mengalami peningkatan berat badan dan tidak beresiko mengalami gizi kurang.

\section{KESIMPULAN}

Teknik menyusui berhubungan signifikan dengan berat badan bayi usia 1-6 bulan dengan $p$-value $=0,003$. Jika teknik menyusui dilaksanakan dengan baik maka berat badan bayi akan meningkat. Frekuensi menyusui berhubungan signifikan dengan berat badan bayi usia 1-6 bulan dengan $p$-value $=0,018$. Semakin sering menyusui maka bayi tidak pernah merasa lapar dan mendapat gizi yang cukup sehingga berat badanya meningkat. Durasi menyusui berhubungan signifikan dengan berat badan bayi usia 1-6 bulan dengan $p$-value $=0,001$. Semakin lama durasi menyusui maka bayi mendapat kandungan gizi ASI yang lebih lengkap sehuingga berat badanya meningkat. Asupan energi berhubungan signifikan dengan berat badan bayi usia 1-6 bulan dengan $p$-value $<0,001$. Jika asupan energi baik maka ibu mendapat energi cukup untuk kebutuhanya dan produksi ASI sehingga bayi mendapat ASI yang cukupdan berat badanya meningkat. Secarabersama sama teknik, frekuensi, durasi menyusui dan asupan energi yang paling berpengaruh terhadap berat badan bayi adalah asupan energi yang dibuktikan dengan $p$-value sebesar 0,003 dan nilai RR/Exp(B) sebesar 38,382 dan dapat menjelaskan berat badan sebesar $68,9 \%$ dan sisanya $31,1 \%$ dijelaskan oleh faktor lain.

\section{ACKNOWLEDGEMENT}

Penulis mengucapkan terima kasih atas dukungan dan masukan dari seluruh staf pengajar pasca sarjana ilmu gizi Universitas Sebelas Maret.

\section{REFERENSI}

1. Kementrian Koordinator Bidang Kesehatan Rakyat RI, 2013. Gerakan Nasional Percepatan Perbaikan Gizi Dalam Rangka Seribu Hari Pertama Kehidupan (Gerakan 1000 HPK). Republik Indonesia.

2. Supariasa. 2012. Penilaian Status Gizi. Jakarta: EGC.

3. Soetjiningsih. 2013. Tumbuh Kembang Anak. Jakarta: EGC.

4. Perinasari. 2004. Management Laktasi. Menuju Persalinan Aman dan Bayi Baru lahir Sehat. Cetakan ke dua. Jakarta: Perinasari.

5. Simanjutak, S. 2005. Gizi Pada Ibu Hamil dan Menyusui. Universitas Sumatra Utara.

6. Kemenkes RI. 2013. Buku Panduan Kader Posyandu Menuju Keluarga Sadar Gizi. Indonesia.

7. Departemen Kesehatan RI. 2007. Pedoman Pemantauan Wilayah Setempat - Gizi (PWS-Gizi). Direktorat Bina Gizi Masyarakat.

8. Johnson, R \& Taylor, W. 2005. Buku Ajar Praktik Kebidanan. Jakarta: EGC.

9. Carpenito, L.J. 2009. Diagnosis Keperawatan dan Aplikasi Praktik Klinis. Jakarta: EGC.

10. Pertiwi, S.H, Solehawati \& Widiasih. 2012. Faktor-Faktor yang Mempengaruhi Proses Laktasi Ibu 
dengan Bayi Usia 0-6 Buan di Desa Cibeusi Kecamatan Jatinangor. Bandung: Jurnal Universitas Padjadjaran.

11. Henderson.C. 2006. Buku Ajar Konsep Kebidanan. Jakarta: EGC.

12. Suradi, R dan Hesti. 2004. Manajemen Laktasi. Program Manajemen Laktasi Perkumpulan Perinatologi Indonesia: Jakarta.

13. WHO. 2011. Pelatihan Konseling Menyusu. World Health Organization: UNICEF.

14. Puapornpong $P$, Raungrongmorakot $K$, Manolerdtewan W, Ketsuwan S, Sinutchanan W. 2015. The Number of Infant Feeding Positions and the 6-Month
Exclusive Breastfeeding Rates. J Med Assoc Thai. 2015 Nov;98(11):1075-8

15. Sattari M, Serwit J, Neal D, Levine D. 2013. Work-Place Predictors of Duration of Breastfeeding among Female Physicians.The Journal of Pediatric Vulume: 163, Issue 6, Pages 1612-1617

16. Adriani, M. Wirjatmadi, B. 2012. Peranan Gizi Dalam Siklus Kehidupan. Jakarta: Kencana.

17. Boone KM, Geraghty SR, Keim SA 2016. Feeding at the Breast and Expressed Milk Feeding: Associations with Otitis Media and Diarrhea in Infants. J Pediatr. 2016 May 9. pii: S0022-3476(16)30054-3. doi: 10.1016/j.jpeds.2016.04.006. [Epub ahead of print] 